\title{
HUBUNGAN USIA, JENIS KELAMIN, DAN KADAR BILIRUBIN DENGAN KOLELITIASIS
}

\section{RELATIONSHIPS OF AGE, SEX AND BIIRUBIN LEVELS WITH COLLITIASIS}

\author{
Sakti Perwira Aji ${ }^{1}$, Resti Arania ${ }^{2}$, Esteria Maharyuni ${ }^{3}$ \\ ${ }^{1,2,3}$ Universitas Malahayati \\ E-mail : saktiperwiraaji98@gmail.com
}

\begin{abstract}
ABSTRAK
Berdasarkan studi kolesistografi oral didapatkan insidensi kolelitiasis terjadi pada wanita sebesar $76 \%$ dan pada laki-laki 36\% dengan usia lebih dari 40 tahun. American Society of Gastrointestinal Endoscopy (ASGE) menempatkan kadar bilirubin 1,8-4 mg/dL sebagai prediktor kuat sedangkan kadar bilirubin $>4$ $\mathrm{mg} / \mathrm{dL}$ sebagai prediktor sangat kuat untuk memprediksi adanya batu duktus koledokus. Tujuan penelitian ini adalah untuk mengetahui hubungan usia, jenis kelamin, dan kadar bilirubin serum dengan kolelitiasis di RSUD Dr. H. Abdul Moeloek Provinsi Lampung. Jenis penelitian analitik observatif dengan desain penelitian retrospektif cross sectional, menggunakan data sekunder rekam medik pasien rawat jalan di di RSUD Dr. H. Abdul Moeloek. Sampel berjumlah 76 orang dengan teknis random sampling. Uji statistic menggunakan Chi-Square. Hasil penelitian didapatkan pasien dengan usia beresiko ( $\geq 40$ th) sebesar $86,8 \%$; jenis kelamin perempuan 61,8\%), dan kadar bilirubin serum meningkat sebesar 59,2\%. Uji statistic menunjukkan terdapat hubungan kolelitiasis dengan usia ( $p$-value $0,024<0,05$; OR 0,222; $95 \%$ CI 0,0550,891 ), terdapat hubungan kolelitiaisis dengan jenis kelamin ( $p$-value $0,047<0,05 ;$ OR 0,$332 ; 95 \%$ CI 0,1101.008),terdapat hubungan kolelitiasis dengan kadar bilirubin serum ( $p$-value $0,023<0,05, O R$ 0,280; $95 \% C I$ $0,090-0,867)$. Terdapat hubungan antara usia, jenis kelamin dan kadar bilirubin dengan kolelitiasis dengan $p$ value $<0,05$.
\end{abstract}

Kata Kunci : bilirubin, jenis kelamin, kolelitiasis, usia

\begin{abstract}
Based on oral cholecystography studies, it was found that the incidence of cholelithiasis occurred in women by $76 \%$ and in men $36 \%$ with age more than 40 years. The American Society of Gastrointestinal Endoscopy (ASGE) places a bilirubin level of $1.8-4 \mathrm{mg} / \mathrm{dL}$ as a strong predictor while a bilirubin level $>4 \mathrm{mg} / \mathrm{dL}$ as a very strong predictor of coledococcal duct stones. The purpose of this study was to determine the relationship between age, sex, and serum bilirubin levels with cholelithiasis in Dr. H. Abdul Moeloek, Lampung Province. This was an observative analytic study with a cross sectional retrospective study design, using secondary data from the medical records of outpatients at Dr. H. Abdul Moeloek. The population was 311 outpatients with clinical symptoms of cholelithiasis. The sample consisted of 76 people using random sampling technique. Statistical test using Chi-Square. The results showed that patients with age at risk ( $\geq 40$ years) were $86.8 \%$; female gender $61.8 \%$ ), and serum bilirubin levels increased by $59.2 \%$. Statistical tests showed that there was a correlation between cholelithiasis and age ( $\mathrm{p}$-value $0.024<0.05$; OR 0.222 ; $95 \%$ CI $0.055-0.891$ ), there was a correlation between cholelithiasis and gender (p-value 0.047 $<0.05$; OR 0.332 ; $95 \%$ CI $0.110-1.008$ ), there is a correlation between cholelithiasis and serum bilirubin levels (p-value $0.023<0.05$, OR 0.280 ; 95\% CI 0.090-0.867). There is a relationship between age, sex and bilirubin levels with cholelithiasis with $\mathrm{p}$ value $<0.05$.
\end{abstract}

Keywords: bilirubin, gender, cholelithiasis, age 


\section{PENDAHULUAN}

Prevalensi penyakit kolelitiasis sangat bervariasi di antara populasi yang berbeda. Prevalensi kolelitiasis antara orang dewasa adalah sekitar 10\% sementara di Eropa Barat prevalensinya berkisar dari 5,9\% hingga 21,9\%. Tingkat prevalensi $3,2 \%$ hingga $15,6 \%$ telah dilaporkan dari Asia. Kolelitiasis lebih sering terjadi pada wanita dibandingkan pria ${ }^{1}$. Menurut Third National Health and Nutrition Examination Survey (NHANES III), prevalensi kolelitiasis di Amerika Serikat yaitu $7,9 \%$ pada laki-laki dan $16,6 \%$ pada perempuan ${ }^{2}$.

Penyakit kolelitiasis sering terjadi pada orang usia 50-70 tahun, dan jarang ditemui pada usia remaja. Semakin bertambahnya usia, semakin besar resiko kolelitiasis ${ }^{3}$. Usia dapat menjadi faktor resiko terjadinya kolelitiasis, disebabkan oleh peningkatan saturasi empedu karena terjadi penurunan aktivitas $7 \alpha$ hidroksilase yang merupakan enzim limiting rate untuk biosintesis kolesterol ${ }^{1}$.

Pasien dengan batu empedu sebagian besar tidak mempunyai keluhan. Risiko penyandang batu empedu untuk mengalami gejala dan komplikasi relatif kecil. Walaupun demikian, pada saat batu empedu mulai menimbulkan serangan nyeri kolik yang spesifik maka resiko untuk mengalami masalah dan penyulit akan terus meningkat ${ }^{4}$.

Penelitian Albab (2013) menyebutkan bahwa insiden terbanyak kolelitiasis terjadi pada pasien dengan kadar bilirubin total kurang $<1,1 \mathrm{mg} / \mathrm{dl}$ dengan jumlah kasus 58 atau sebesar $66,66 \%$, dan pasien dengan kadar bilirubin total > 1,1 mg/dl dengan jumlah kasus 29 atau sebesar $33,33 \%$.
Bilirubin adalah pigmen kuning yang merupakan hasil pemecahan sel darah merah, yang disekresikan ke dalam empedu oleh sel hepar. Beberapa kondisi hematologis dapat menyebabkan bilirubin di ekskresi terlalu banyak melalui pemecahan hemoglobin sehingga bilirubin yang berlebihan dapat menyebabkan kolelitiasis ${ }^{6}$. American Society of Gastrointestinal Endoscopy (ASGE) menempatkan kadar bilirubin 1,8-4 mg/dL sebagai prediktor kuat sedangkan kadar bilirubin $>4 \mathrm{mg} / \mathrm{dL}$ sebagai prediktor sangat kuat untuk memprediksi adanya batu duktus koledokus? ${ }^{7}$.

Tujuan penelitian ini adalah untuk mengetahui hubungan usia, jenis kelamin, dan kadar bilirubin serum dengan kolelitiasis di RSUD Dr. H. Abdul Moeloek Provinsi Lampung.

\section{METODE}

Metode penelitian ini adalah analitik observatif dengan desain penelitian retrospektif cross sectional, dimana variabel sebab atau risiko dan akibat dikumpulkan dalam waktu yang bersamaan dari data rekam medis pasien rawat jalan tahun 2018. Penelitian ini akan dilakukan di RSUD Dr. H. Abdul Moeloek Provinsi Lampung dan waktu penelitian pada bulan Agustus 2020

Populasi adalah keseluruhan objek penelitian atau objek yang diteliti. Populasi pada penelitian ini adalah 311 pasien rawat jalan dengan gejala klinis kolelitiasis RSUD Dr. H. Abdul Moeloek Provinsi Lampung tahun 2018.

Kriteria inklusi pada penelitian ini adalah semua pasien yang menunjukan gejala klinis kolelitiasis, pasien baru yang telah yang telah dicek kadar bilirubin serum, data rekam medik lengkap. Sampel yang digunakan berjumlah 76 orang dengan teknik pengambilan sampel 
random sampling. Instrumen penelitian menggunakan aplikasi IBM SPSS 21.0 dengan uji statistic chi square.

\section{HASIL}

Tabel 1. Hubungan Usia dengan Kolelitiasis Di RSUD Dr. H. Abdul Moeloek Provinsi Lampung

\begin{tabular}{lccccccc}
\multicolumn{8}{c}{$\mathbf{n}=76$} \\
\hline Variabel & \multicolumn{7}{c}{ Usia } \\
& $\begin{array}{c}\text { Tidak } \\
\text { Beresiko }\end{array}$ & Beresiko & $\begin{array}{c}\boldsymbol{p} \text { - } \\
\text { value }\end{array}$ & OR & $\begin{array}{c}\boldsymbol{C I} \\
\mathbf{9 5 \%}\end{array}$ \\
& $\mathrm{n}$ & $\%$ & $\mathrm{~N}$ & $\%$ & & & \\
\hline Tidak & 5 & 29,4 & 12 & 70,6 & & & \\
Kolelitiasis & & & & & 0,024 & 0,222 & $(0,055-$ \\
Kolelitiasis & 5 & 8,5 & 54 & 91,5 & & & $0,891)$ \\
\hline
\end{tabular}

Berdasarkan tabel diatas didapatkan bahwa responden dengan kolelitiasis dengan usia yang tidak beresiko (<40th) berjumlah $5(8,5 \%)$, sedangkan responden dengan kolelitiasis yang mempunyai usia beresiko ( $\geq 40$ th) berrjumlah 54 responden $(91,5 \%)$. Uji statistic didapatkan $p$ value $0,024<0,05$ dengan nilai OR $0,222 \quad(95 \%$ CI 0,055-0,891) yang berarti bahwa terdapat hubungan antara usia dengan kejadian kolelitiasis di RSUD Dr. H. Abdul Moeloek Provinsi Lampung.

Tabel 2. Hubungan Jenis Kelamin dengan Kolelitiasis Di RSUD Dr. H. Abdul Moeloek Provinsi Lampung

\begin{tabular}{lccccccc}
\multicolumn{8}{c}{ n=76 } \\
\hline Variabel & Laki-Laki & Perempuan & $\begin{array}{c}p \text { - } \\
\text { value }\end{array}$ & OR & CI 95\% \\
& $\mathrm{n}$ & $\%$ & $\mathrm{n}$ & $\%$ & & & \\
\hline Tidak & 10 & 58,8 & 7 & 41,2 & & & $0,110-$ \\
Kolelitiasis & 19 & 32,2 & 40 & 77,8 & 0,047 & 0,332 & 1008 \\
Kolelitiasis & 19 & & & & & & \\
\hline
\end{tabular}

Berdasarkan tabel diatas diketahui bahwa responden kolelitiasis yang berjenis kelamin laki-laki berjumlah 19 orang $(32,2 \%)$,

sedangkan responden kolelitiasis berjenis kelamin perempuan berjumlah $40(77,8 \%)$, uji statistic menunjukkan p-value $0,047<0,05$ dengan nilai $O R \quad 0,332 \quad(95 \%$ CI $0,110-1.008)$ yang berarti bahwa terdapat hubungan antara jenis kelamin dengan kejadian kolelitiasis di RSUD Dr. H. Abdul Moeloek Provinsi Lampung.

Tabel 3. Hubungan Kadar Bilirubin Serum dengan Kolelitiasis Di RSUD Dr. H. Abdul Moeloek Provinsi Lampung $n=76$

\begin{tabular}{|c|c|c|c|c|c|c|c|}
\hline \multirow{3}{*}{ Variabel } & \multicolumn{4}{|c|}{ Kadar Bilirubin Serum } & \multirow{2}{*}{$\begin{array}{c}p- \\
\text { value }\end{array}$} & \multirow[b]{2}{*}{ OR } & \multirow{2}{*}{$\begin{array}{c}C I \\
95 \%\end{array}$} \\
\hline & \multicolumn{2}{|c|}{ Normal } & \multicolumn{2}{|c|}{ Meningkat } & & & \\
\hline & $\mathrm{n}$ & $\%$ & $\mathrm{n}$ & $\%$ & & & \\
\hline Tidak & 11 & 64,7 & 6 & 35,3 & & & \\
\hline $\begin{array}{l}\text { Kolelitiasis } \\
\text { Kolelitiasis }\end{array}$ & 20 & 33,9 & 39 & 66,1 & 0,023 & 0,280 & $\begin{array}{c}0,090- \\
0.867\end{array}$ \\
\hline
\end{tabular}

Berdasarkan tabel diatas diketahui bahwa responden kolelitiasis dengan kadar bilirubin normal sebanyak 20 orang (33,9\%),sedangkan responden kolelitiasis dengan kadar bilirubin meningkat sebanyak $39(66,1 \%)$. Uji statistic chi-square diperoleh hasil $p$-value $0,023<0,05$ dengan nilai $O R \quad 0,280 \quad(95 \%$ CI $0,090-0,867)$ yang berarti bahwa terdapat hubungan antara kadar bilirubin serum dengan kejadian kolelitiasis Di RSUD Dr. H. Abdul Moeloek Provinsi Lampung.

\section{PEMBAHASAN}

\section{Hubungan Usia dengan Kolelitiasis}

Responden dengan usia beresiko ( $\geq 40$ th) akan memiliki resiko 0,22 kali lebih besar untuk menderita kolelitiasis dibandingkan dengan responden dengan usia tidak beresiko ( $<40$ th). Penelitian ini mendukung teori bahwa penyakit kolelitiasis sering terjadi pada orang usia 50-70 tahun, dan jarang ditemui pada usia remaja. Semakin bertambahnya usia, semakin besar resiko kolelitiasis ${ }^{3}$. Usia dapat menjadi faktor resiko terjadinya kolelitiasis, disebabkan oleh peningkatan saturasi empedu karena terjadi penurunan aktivitas $7 \alpha$ hidroksilase yang merupakan enzim limiting rate untuk biosintesis kolesterol $^{1}$.

Hasil ini sesuai dengan penelitian yang dilakukan Soeta (2017) di RSUP DR Wahidin Sudirohusodo menunjukkan kasus kolelitiasis 
tertinggi pada usia 40-49 tahun yaitu 31 kasus $(35,63 \%)^{7}$. Hasil yang sama ditemukan pada hasil penelitian Gyedu tahun 2015, bahwa usia $\geq 40$ tahun sebesar 1737 (61,5\%)(3). Temuan lain yang sesuai adalah penelitian Dani tahun 2012 di RS Immanuel Bandung kasus kolelitiasis tertinggi usia 40- 49 tahun $(33,33 \%)^{8}$.

Penelitian ini tidak sejalan dengan penelitian oleh Soeta pada tahun 2017 yaitu terdapat hubungan yang bermakna $(\mathrm{p}=0,001)$ antara umur kurang dari 40 tahun dengan kejadian batu empedu yang mana nilai rasio prevalensi 2,05. Ini berarti bahwa umur kurang dari 40 tahun merupakan risiko potensial untuk terjadinya batu empedu 2 kali lebih besar dari orang yang berumur diatas 40 tahun ${ }^{9}$.

\section{Hubungan Jenis Kelamin dengan Kolelitiasis}

Jenis kelamin perempuan mempunyai resiko 0,332 kali lebih besar untuk menderita kolelitiasis dibandingkan dengan responden dengan jenis kelamin laki-laki. Wanita mempunyai resiko 3 kali lipat untuk terkena batu empedu dibandingkan dengan pria. Hal ini dikarenakan oleh hormon esterogen yang berpengaruh terhadap peningkatan eskresi kolesterol oleh kandung empedu. Pada kehamilan, terjadi peningkatkan kadar esterogen juga dapat meningkatkan resiko terkena batu empedu. Penggunaan pil kontrasepsi dan terapi hormone (esterogen) dapat meningkatkan kolesterol dalam kandung empedu dan penurunan aktivitis pengosongan kandung empedu ${ }^{1}$.

Penelitian ini juga sejalan dengan penelitian oleh Soeta (2017) yaitu terdapat hubungan yang bermakna $(p=0,001)$ antara jenis kelamin perempuan terhadap kejadian batu empedu yang mana nilai rasio prevalensi 3,38 , ini berarti jenis kelamin perempuan merupakan risiko potensial untuk terjadinya batu empedu 3 kali lebih besar dari pada laki-laki ${ }^{9}$.

\section{Hubungan kadar Bilirubin Serum dengan Kolelitiasis}

Bilirubin adalah pigmen kuning yang merupakan hasil pemecahan sel darah merah, yang disekresikan ke dalam empedu oleh sel hepar. Beberapa kondisi hematologis dapat menyebabkan bilirubin diekskresi terlalu banyak melalui pemecahan hemoglobin sehingga bilirubin yang berlebihan dapat menyebabkan kolelitiasis ${ }^{6}$.

Patogenesis batu pigmen melibatkan infeksi saluran empedu, statis empedu, malnutrisi, dan faktor diet. Kelebihan aktivitas enzim bglucuronidase bakteri dan manusia (endogen) memegang peran kunci dalam patogenesis batu pigmen pada pasien di daerah timur hidrolisis bilirubin oleh enzim tersebut akan membentuk bilirubin tak terkonjugasi yang akan mengendap sebagai kalsium bilirubinate. Enzim bglucuronidase bakteri berasal dari kuman e.coli dan kuman lainnya di saluran empedu. Enzim ini dapat dihambat oleh glucarolactone yang konsentrasinya meningkat pada pasein dengan diet rendah protein dan rendah lemak(10). Ikterus terjadi karena adanya refluks bilirubin direk dari saluran empedu kedalam darah karena adanya hambatan aliran empedu menyebabkan tingginya kadar bilirubin di dalam darah ${ }^{11}$.

Karsinoma pada saluran empedu ekstra hepatik jarang terjadi. Pertumbuhan tumor ini sering tersembunyi sampai tumbuhnya menyebabkan obstruksi aliran empedu sehingga terjadi icterus obstruksi $^{12}$.

Nilai normal kadar bilirubin serum total adalah $\leq 1,4 \mathrm{mg} / \mathrm{dL}$ untuk bilirubin langsung $\leq 0,40$ $\mathrm{mg} / \mathrm{Dl}^{12}$. American Society of Gastrointestinal Endoscopy (ASGE) me-nempatkan kadar bilirubin $1,8-4 \mathrm{mg} / \mathrm{dL}$ sebagai prediktor kuat sedangkan kadar bilirubin $>4 \mathrm{mg} / \mathrm{dL}$ sebagai prediktor sangat kuat untuk memrediksi adanya batu duktus koledokus ${ }^{13}$.

Menurut penelitian oleh Dutt (2013). Konsentrasi bilirubin tak terkonjugasi yang dinyatakan sebagai proporsi dari total bilirubin yang ada secara signifikan lebih tinggi pada 
kelompok batu empedu kolesterol (kelompok batu empedu kolesterol: rata-rata, 3,41\%; median, 3,04\%; SD, 1,4\%; $\mathrm{n}=20$; kontrol: ratarata, $1,74 \%$; median $1,51 \% ; \mathrm{SD}, 0,8 \% ; \mathrm{n}=8 ; \mathrm{p}$ $<0,002)^{14}$.

Ada korelasi yang lebih baik antara proporsi bilirubin tak terkonjugasi dan keberadaan batu daripada indeks saturasi kolesterol klasik, meningkatkan kemungkinan bahwa proporsi bilirubin terkonjugasi menjadi tak terkonjugasi dan / atau monokonjugasi mungkin penting dalam nukleasi kolesterol, atau bahwa itu hanyalah penanda aktivitas glukuronidase terkait dengan motilitas kandung empedu yang buruk. Banyak penelitian telah menekankan peran gangguan motilitas kandung empedu dan usus dalam patogenesis penyakit kolesterol batu empedu, dan gangguan motilitas kandung empedu akan mendukung pembentukan bilirubin tak terkonjugasi ${ }^{14}$.

\section{KESIMPULAN}

Terdapat hubungan antara usia, jenis kelamin dan kadar bilirubin dengan kolelitiasis di RSUD Dr. H. Abdul Moeloek dengan $p$ value $<0,05$. Disarankan agar di berikan edukasi tentang pola hidup sehat dan melakukan screning kesehatan secara rutin kepada masyarakat terutama pada kelompok kelompok risiko tinggi yang disebut "5 F": female, fertile, fat, fair, dan forty.

\section{DAFTAR PUSTAKA}

1. Gabriel E N. Gallstones. PubMed. 2013;19(2):49-55.

2. Chuang, Hsi shih chang \&, Lee E\&, King-Teh. Genetics of Gallstone Disease. adv Clin Chem. 2013;60:85143.

3. Gyedu A, KA A, AB P. Prevalence of Kolelitiasis among persons undergoing abdominal ultrasound at the Komfo Anokye teaching Hospital, Kumasi, Ghana. Afr Health Sci. 2015;246-52.

4. Cahyono B. Tatalaksana Klinis di Bidang Gastro dan Hepatologi. Jakarta: Sugeng Seto; 2014.
5. Albab A. Karakteristik Pasien Kolelitiasis Di Rsup Dr. Wahidin Sudirohusodo Makassar Periode JanuariDesember 2012. Fak Kedokt Univ Hasanuddin Makassar. 2013;

6. Tanaja J, Meer J. Kolelitiasis. StatPearls. 2017;

7. American Society for Gastrointestinal EndoscopyASGE. Guideline: colorectal cancer screening and surveillance [Internet]. 2006. Available from: http://www.asge.org/uploadedFiles/Publi cations_and_Products/Practice_Guidelin es/2006_colorectal.pdf

8. Susilo L. Karakteristik Pasien Cholelithiasis Di Rumah Sakit Immanuel Bandung Periode 1 Januari 2012-31 Desember 2012. Dr Diss Univ Kristen Maranatha. 2014;

9. Sueta M., Warsinggih. Faktor Resiko Terjadinya Batu Empedu Di RSUP DR. Wahidin Sudirohusodo Makassar. J Bedah Nas. 2017;

10. Lesmana L, Nusi I, Gani R, Hasan I, Sanityoso A, Lesmana C, et al. Panduan praktik klinik penatalaksanaan ensefalopati hepatik di Indonesia 2014. jakarta: Perhimpunan Peneliti Hati Indonesia; 2014.

11. Tuuk A., Panelewen J, Noersasongko A. Profil kasus batu empedu di RSUP Prof. Dr. RD Kandou Manado periode Oktober 2015-Oktober 2016. e-CliniC. 2016;4(2).

12. Keputusan Mentri Kesehatan Republik Indonesia. Pedoman interpretasi data klinik. jakarta: Kementrian Kesehatan RI; 2011.

13. Rista D, Soetikno. Imaging keganasan Pankreatobiliaris. Bandung: Bagian Radiologi FK UNPAD; 2007.

14. Dutt M., Murphy G., Thompson RP. Unconjugated bilirubin in human bile: the nucleating factor in cholesterol cholelithiasis? J Clin Pathol. 2003;56(8):596-8. 